\title{
COLLABORATIVE NETWORKS AND TOURISM MANAGEMENT OF PERI-URBAN FORESTS
}

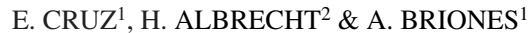 \\ ${ }^{1}$ Universidad Autónoma del Estado de Hidalgo. Mexico \\ ${ }^{2}$ Universidad de Quintana Roo. Mexico
}

\begin{abstract}
El Chico National Park (ECNP) is one of the most important peri-urban forests in the state of Hidalgo. Tourism management of this park involves numerous stakeholders with different needs, resources and perceptions of nature. There are four forest communities that are involved in the use of this park for tourism activities, but there are other stakeholders: federal government agencies, state government agencies, municipalities, unorganized smallholder entrepreneurs. Tourism management of this peri-urban forest is a complex issue, particularly, when decision-making processes are centralised by government bodies. This study explores the relationships' structure among government agencies and Community Tourism Associations (CTAs) based on the tourism management of ECNP. This study presents a descriptive analysis of collaborative networks among the park's stakeholders, using a qualitative research approach.

Keywords: collaborative networks, government bodies, protected areas, stakeholders, tourism management.
\end{abstract}

\section{INTRODUCTION}

Collaborative networks are systems that support tourism organization in natural spaces. It has been shown that collaborative actions have become the basis for the development of environmentally sustainable tourism $[1,2]$. Since not all natural spaces can be managed properly through government regulation alone, an active involvement of a wide range of stakeholders from the public, private and non-profit sectors is required.

ECNP is one of the most important peri-urban forests in the state of Hidalgo. Tourism management of this park involves numerous stakeholders with different needs, resources and perceptions of nature. There are four forest communities that are involved in the tourism use of this park. Each one of them, is responsible for the valleys' management, which are located around this peri-urban forests. There are other stakeholders behind tourism activities in this park: federal government agencies, state government agencies, municipalities, unorganized smallholder entrepreneurs.

Tourism management of this park is a complex issue, particularly, when there is not a trend of devolving control over natural resources from government to user groups. This study explores the relationships' structure among government agencies and CTAs based on the tourism management of ECNP. Through the analysis of relationships and the empirical evidence, the social networks in tourism processes are described. This paper focuses on: a) identifying stakeholder categories and their key activities in ECNP's tourism management and b) describing general patterns of cooperation among stakeholders. 


\section{COLLABORATION NETWORKS AND TOURISM MANAGEMENT OF PERI-URBAN FORESTS}

In many economically developed regions of the world, the present process of urbanization and population growth involves a loss of contact with nature for those living in populated areas such as city centres, industrial cities and commercial centres. However, the demands of urban life have stimulated a desire for contact with nature though the practice of tourism and recreational activities in natural spaces such as horseback riding, camping, hiking, mountain biking, jogging, picnicking [3,4]. Traditional products of the forests usually had something to do with material resources, but currently, the role of these ecosystems has changed in rural areas [5]. The tendency of urban residents who want to escape from their routine life in periurban areas on weekends and holidays has increased in the last decades [6]. Peri-urban forests, particularly, have become important recreational systems; they are the main outdoor playing places for tourists and urban residents in their leisure time.

Peri-urban forests began to take on a recreation function in industrial and urban cities to provide residents with opportunities of getting closer to nature. But they are also providing economic alternatives to host communities and stakeholders involved in tourism management. Peri-urban forests have become a significant factor in rural development, particularly in those areas where landscapes have ceased to be directly involved in food production due to the "commodification" of certain natural resources.

This on-going functional change has increased the pressure on natural spaces; tourism development in peri-urban forests has generated negative effects such as loss of native species, deforestation and environmental degradation [7-9]. Ecological degradation is caused by the massive influx and outflow of visitors to these recreation areas; but it is also caused by a lack of stakeholders' involvement in sustainable management of tourism. Some studies report that management problems on forests and peri-urban forests are due to a lack of information about expectations and social needs of user groups [10,11].

Tourism management in forests and peri-urban forests is a complex task, due to the diverse public and private stakeholders involved in tourism by providing infrastructure, services, information and primary and secondary tourism products [12]. Along with the emergence of tourism in this ecosystem, stakeholders who are involved in tourism management have to confront different problematic situations with regard to the development of this activity. Some of the significant challenges are social and structural legitimacy, government accountability, environmental degradation, social inequality and socio-economic impacts of tourism on host communities [13]. However, the low level of participation of local communities in knowledge exchange, environmental management and the decision-making processes, are some of the most important critical situations in these ecosystems [14,15].

Tourism management of forests and peri-urban forests demands a social structure and institutional arrangements to promote information flow, knowledge transfer, innovation exchange and learning opportunities [16,17]. In order to incorporate systems of governance, a decentralization process is needed in which government bodies implement political, fiscal and decision-making devolution from central government to local stakeholders. Social networks can bring many benefits, for example, helping to decrease transaction costs, leading to more innovative activities and allowing a large number of small actors with limited resources to take part in the decision-making process and promotion of environmental conservation $[18,19]$. Inter-organizational relationships are a key factor in planning strategies which guarantee a level of environmental conservation and economic development for host communities and stakeholders directly or indirectly linked with the tourism use of peri-urban 
forests. Relational approaches in social networks, allow identifying who plays the main role in decision-making processes, explore the interdependency among stakeholders and identify the type of ties between them [20].

\section{TOURISM DEVELOPMENT IN EL CHICO NATIONAL PARK}

In the state of Hidalgo peri-urban forest areas cover 454, 486 ha, representing $55.59 \%$ of the total surface area of the state. Coniferous forests and pine-mixed oak forests are present in two of the most important national parks in the country: El Chico Park and Los Mármoles Park [21]. The first one is located on the borders of the city of Pachuca, the most populated and capital city in the state. This park is not only an important space for the city's residents recreation but its' closeness to Mexico's city has made it one of the most important tourist destination in the region. When this park was declared as a protected area (1982), the environmental policy was tightened. Since 1990, the federal government has stimulated tourism activities as a new economic alternative to combat poverty and environmental degradation in the region. Communities located on the surrounding area provide a range of activities such as the sale of food, horseback riding, cabin rentals and camping services. This communitybased tourism model appears to be successful. However, tourist services are quite repetitive and, overall, are considered similar in all the regions' valleys. On the other hand, the quantity of infrastructure is insufficient to support tourism activities and that generate an intensive use of natural resources.

There are four forest communities involved in the tourism use of this park, an activity that constitutes their primary economic activity. Each one of them manages tourism activities in the valleys that are located around the park. To manage these valleys, local communities have formed four Community Tourism Associations (CTAs). Development policies have promised to involve state agencies and non-state actors in the tourism use of the park's natural resources. Currently, governance structures as "collaborative management" have become a dominant policy trend in tourist management of this park.

\section{METHODOLOGY}

Participation in collaborative networks is considered a crucial precondition for sustainable management based on tourism. Using this as a starting point, we are interested in: a) identifying stakeholder categories and their key activities in ECNP's tourism management, and b) describing general patterns of cooperation between CTAs and government bodies.

To identify stakeholders and their key activities, we conducted an iterative stakeholder analysis involving semi-structured interviews and informal meetings with public managers and CTA's members. A series of 25 face-to-face interviews with key informants were conducted between January and March 2015. Stakeholder categories were derived from the research questions as well as issues emerging from the data. According to similarities and differences in roles, we distinguished a typology of stakeholders by introducing three attributes: a) their influence on the network, b) their logic of action and c) their action on the territory. In many interviews, we also identified stakeholders' roles and their activities. These "key activities" were eventually placed in five categories that emerged from this analytical process: 1) Natural resource management (NRM), 2) Creation of tourist services (CTP), 3) Tourism destination management (TDM), 4) Promotion (PRO) and 5) Marketing (MKT).

To describe the general patterns of cooperation among stakeholders, we used social network analysis (SNA). We used asymmetric matrices to organize the data, one for each 
"key activity". In the matrices, the 15 stakeholders were represented twice: once in the row and once in the column. In asymmetric matrices, the ties may or may not be reciprocal, and they also represent the intensity of a tie by the values found within the cell. Two indicators were important to determine the importance of stakeholders in tourism management of this park: degree centrality and betweenness centrality [22]. In-degree centrality, two indicators can be distinguished: in-degree and out-degree centrality. Both are formally defined as:

$$
C_{S, \text { in }}\left(n_{i}\right)=\sum_{j=1}^{l} r_{i j, \text { in }} ; C_{S, \text { out }}\left(n_{i}\right)=\sum_{j=1}^{l} r_{i j, \text { out }} ;
$$

where and, denote one of inward and outward connections of node $i$, and $l$ indicates the number of nodes within the network. In-degree centrality of a node $i$ is the sum of the number of nodes $j$ in the network that connect inward (from node $j$ to node $i$ ); out-degree centrality of a node $i$ is the sum of the number of nodes $j$ in the network that connect outwardly [22].

The betweenness centrality of a node is defined as:

$$
C_{S}\left(n_{i}\right)=\sum_{j}^{l} \sum_{k}^{l} \frac{g_{j k}\left(n_{i}\right)}{g_{j k}}, j \neq k \neq i,
$$

where denotes the number of geodesics between nodes $j$ and $k$, and denotes the number of geodesics linking the two nodes that contain node $i$ [22].

\section{IDENTIFYING STAKEHOLDERS AND ANALYSING THEIR ROLES}

The selection of stakeholders allows us to understand the social and institutional structures through which they support tourism and manage this ecosystem. Above all, selection of stakeholders is important to identify the main groups who are capable of: a) controlling and mobilizing all types of resources, b) making decisions about these resources, and c) involving stakeholders groups in strategic decisions about the course of tourism development. A set of public and private stakeholders are involved in activities ranging from management of natural resources to tourism services marketing. These activities play a central role in knowledge transfer and innovation diffusion.

Relationships among stakeholders bring collaborative trust and some fresh and heterogeneous knowledge. However, tourism management is a complicated task because there are many actors behind tourism activities in the ECNP: federal government agencies, state government, the municipalities, local communities, CTAs, unorganized smallholder entrepreneurs, tourists and visitors. The list could be longer. In Annex 1, we conclude that these stakeholder categories are the most influential, and they were organized according to how they are most likely to potentially be affected by the tourism management of ECNP.

\subsection{Collaborative networks based on natural resource management}

The past decades have witnessed a major policy trend of devolving control over natural resources from government agencies to user groups. This process involves the transfer of control from the state to non-governmental stakeholders but, in Mexico, the state retains the main role in tourism management. In the network based on NRM, we observed the following behaviours among stakeholders (see Table 1): 
Table 1: Centrality and betweenness based on NRM.

\begin{tabular}{|c|c|c|c|}
\hline \multirow[b]{2}{*}{ Stakeholders } & \multicolumn{2}{|c|}{ Centrality } & \multirow[b]{2}{*}{ Betweenness } \\
\hline & Out & In & \\
\hline PROFEPA & 14 & $14^{*}$ & $40.376^{\alpha}$ \\
\hline SEMARNAT & 14 & $12^{*}$ & $24.376^{\alpha}$ \\
\hline CONAFOR & 12 & $13^{*}$ & $20.543^{\alpha}$ \\
\hline CONANP & 10 & $12^{*}$ & $12.15^{\ltimes}$ \\
\hline HAPS & $6^{*}$ & $3^{*}$ & $0.000^{a}$ \\
\hline HAMM & $5^{*}$ & $5^{*}$ & $0.000^{\alpha}$ \\
\hline HAMC & $4^{*}$ & $6^{*}$ & $0.000^{\alpha}$ \\
\hline ATELE & $7^{*}$ & $4^{*}$ & $0.143^{\alpha}$ \\
\hline ATEC & $7^{*}$ & $4^{*}$ & $0.143^{\alpha}$ \\
\hline ATENP & $7^{*}$ & $3^{*}$ & $0.000^{\mathrm{a}}$ \\
\hline
\end{tabular}

Source: Author's data

- The indicators demonstrate that federal government agencies related to environmental protection (PROFEPA, SEMARNAT, CONAFOR and CONANP) have the highest centrality and betweeness, which means that they are linked to CTAs through mechanisms that are compatible with conservation and tourism development such as reforestation, environmental education and other forests management practices.

- Municipalities (HAPS, HAMM, HAMC) neither play a role as decision makers nor as facilitators between federal government bodies and CTAs.

- They maintain some relationships with other stakeholders (see in-degree centrality and betweenness in Table 1) but are not strong enough to play a role as "brokers".

- CTAs (ATELE, ATEC, ATENP) depend on these government bodies for defining forest use conditions to guarantee sustainable tourism development in the park. They do not consider creating their own initiatives.

\subsection{Collaborative networks based on the creation of tourist services}

One of the challenges of tourism development in this park is maintaining strong relationships between public and private stakeholders to create innovative tourism services. The indicators of this relationship are related to the CTS show that (see Table 2):

- The State Ministry of Tourism and Culture (STYC) is responsible for promoting innovation and providing technical tools to develop innovative tourism services; however, it possesses low degrees of centrality and betweenness.

- Once again, environmental protection agencies (CONAFOR and SEMARNAT) tend to dominate decision making in this network, in fact, they play a key role in the design of tourism infrastructure as a part of the CTS.

- SEDESOL is the most important player in this network. One of its main responsibilities is to provide economic support to primary activities; this has been channelled through 
Table 2: Centrality and Betweenness based on CTS.

\begin{tabular}{|c|c|c|c|}
\hline \multirow[b]{2}{*}{ Stakeholders } & \multicolumn{2}{|c|}{ Centrality } & \multirow[b]{2}{*}{ Betweenness } \\
\hline & Out & In & \\
\hline SEDESOL & $10^{*}$ & $9^{*}$ & $49.804^{\alpha}$ \\
\hline CONAFOR & $8^{*}$ & $4^{*}$ & $13.961^{\infty}$ \\
\hline SEMARNAT & $7^{*}$ & $4^{*}$ & $7.27^{x}$ \\
\hline $\mathrm{SE}$ & $7^{*}$ & $2^{*}$ & $9.411^{\text {म }}$ \\
\hline CONANP & $7^{*}$ & $0^{*}$ & 9.411 \\
\hline STYC & $4^{*}$ & $3^{*}$ & $1.576^{\mathrm{a}}$ \\
\hline HAPS & $1^{*}$ & $3^{*}$ & $0.633^{\alpha}$ \\
\hline HAMM & $0^{*}$ & $6^{*}$ & $0.000^{\alpha}$ \\
\hline HAMC & $2^{*}$ & $6^{*}$ & $1.783^{a}$ \\
\hline ATEC & $5^{*}$ & $8^{*}$ & $6.292^{\alpha}$ \\
\hline ATELE & $5^{*}$ & $8^{*}$ & $3.25^{\ltimes}$ \\
\hline ATEPN & $5^{*}$ & $4^{*}$ & $1.783^{\text {a }}$ \\
\hline
\end{tabular}

Source: Author's data

micro and small tourism enterprises. SEDESOL is an intermediary for the flow of communication.

- The indicators reveal that municipalities (HAPS, HAMM, HAMC) are the stakeholders least involved with the CTS. According to the governmental structure, municipalities should play an important role as brokers as well as to mobilize others in a network of inter-organizational relationships.

Although CTAs (ATELE, ATEC, ATENP) have developed stronger relationships with fedral government bodies than with municipalities (see out-centrality in Table 2), they should be leading the innovation processes. It seems that they have ignored that consumer behaviour in tourism consumption has been changing extensively.

\subsection{Collaborative networks based on tourism destination management}

The main activities involved in this network are: human resource education/training, improvement of infrastructure and implementing tourism certification schemes. In the past, economic activities carried out by local people had nothing to do with the tourism industry. This is one of the reasons why people are lacking an appropriate service orientation. The indicators in this network showed that (see Table 3):

- Government agencies such as State Ministry of Economy (SE) have the strongest influence on CTAs and have benefited them in terms of infrastructure and equipment by promoting economic development programs aimed at creating new small tourism businesses.

- SEDESOL and SE are the central actors in TDM. Particularly SEDESOL has been recognized as the main broker in this network for its exclusive links that have been used to promote an appropriate tourism management in this park. 
Table 3: Centrality and Betweenness based on TDM.

\begin{tabular}{|c|c|c|c|}
\hline \multirow[b]{2}{*}{ Stakeholders } & \multicolumn{2}{|c|}{ Centrality } & \multirow[b]{2}{*}{ Betweenness } \\
\hline & Out & In & \\
\hline SEDESOL & $8^{*}$ & $7^{*}$ & $49.804^{\alpha}$ \\
\hline SE & $8^{*}$ & $4^{*}$ & $0.833^{\ltimes}$ \\
\hline STYC & $7^{*}$ & $7^{*}$ & $1.576^{\infty}$ \\
\hline SEMARNAT & $4^{*}$ & $7^{*}$ & $6.292^{\alpha}$ \\
\hline CONAFOR & $4^{*}$ & $1^{*}$ & $7.270^{\text {ळ }}$ \\
\hline CONANP & $2^{*}$ & $2^{*}$ & $0.000^{\alpha}$ \\
\hline PROFEPA & $1^{*}$ & $1^{*}$ & $0.000^{\mathrm{\alpha}}$ \\
\hline HAPS & $4^{*}$ & $0^{*}$ & $0.633^{x}$ \\
\hline HAMM & $4^{*}$ & $3^{*}$ & $0.000^{\alpha}$ \\
\hline HAMC & $5^{*}$ & $4^{*}$ & $1.783^{\infty}$ \\
\hline ATEC & $5^{*}$ & $7^{*}$ & $9.411^{\ltimes}$ \\
\hline ATELE & $5^{*}$ & $7^{*}$ & $9.411^{\mathrm{x}}$ \\
\hline ATEPN & $5^{*}$ & $4^{*}$ & $0.776^{\ltimes}$ \\
\hline
\end{tabular}

Source: Author's data

- It is important to emphasise that environmental protection agencies (SEMARNAT, CONANP, CONAFOR) have tried to be active brokers in tourism management; however, they neither play a role as central players nor as brokers in the network. Nevertheless they are responsible for the implementation of environmental policies to control and regulate tourism activities (see centrality and betweenness in Table 3).

\subsection{Collaborative networks: Promotion (PRO) and Marketing (MKT)}

In Mexico, many states are designing government-sponsored tourism websites, in the hope that tourists can access information about their potential destinations by browsing them. Official tourism websites of some states have also become a significant means of advertising the local cultures and natural resources of tourist destinations. In the case of the state of Hidalgo, the design of effective government tourism websites has not received attention.

Currently, government actions (federal and state government) are focused on promoting cultural tourist destinations such as Huasca de Ocampo, Real del Monte, Mineral del Chico and Huichapan. Ecotourism development is at a very early stage of development in the state. Governmental programmes in ecotourism have not involved any sort of promotion and marketing.

Even though the local government has had an important role in tourism marketing, it has been criticized for not being more proactive. According to indicators, it was found that:

- In spite of STYC and the municipalities having the highest degrees of centrality, none of them have managed effective and creative promotional campaigns for this park.

- CTA members have created their own tourism destination marketing efforts; they have 
Table 4: The central stakeholders involved on the PRO and MKT.

\begin{tabular}{|c|c|c|c|c|c|c|}
\hline & \multicolumn{3}{|c|}{ Promotion } & \multicolumn{3}{|c|}{ Marketing } \\
\hline & \multicolumn{2}{|c|}{ Centrality } & \multirow[b]{2}{*}{ Betweenness } & \multicolumn{2}{|c|}{ Centrality } & \multirow[b]{2}{*}{ Betweenness } \\
\hline & Out & In & & Out & In & \\
\hline STYC & $6^{*}$ & $6^{*}$ & $28^{\alpha}$ & $2^{*}$ & $2^{*}$ & $2^{\alpha}$ \\
\hline HAMC & $3^{*}$ & $1^{*}$ & $0^{\alpha}$ & $0^{*}$ & $0^{*}$ & $0^{\alpha}$ \\
\hline HAPS & $1^{*}$ & $1^{*}$ & $0^{\alpha}$ & $0^{*}$ & $0^{*}$ & $0^{\alpha}$ \\
\hline ATESMC & $1^{*}$ & $1^{*}$ & $0^{\alpha}$ & $0^{*}$ & $0^{*}$ & $0^{\alpha}$ \\
\hline HAMM & $1^{*}$ & $1^{*}$ & $0^{\alpha}$ & $0^{*}$ & $0^{*}$ & $0^{\alpha}$ \\
\hline ATEC & $1^{*}$ & $2^{*}$ & $0^{\alpha}$ & $3^{*}$ & $1^{*}$ & $1^{\propto}$ \\
\hline ATELE & $1^{*}$ & $2^{*}$ & $0^{a}$ & $3^{*}$ & $1^{*}$ & $1^{\infty}$ \\
\hline
\end{tabular}

Source: Author's data

developed some instruments for promoting tourism but these are limited to a local scale. They are weakly involved in this network (see centrality and betweenness in Table 4).

- Government programmes aimed at marketing strategies are limited, in addition to this, CTAs have been inactive in these strategies, thus relationships based on promotion and marketing are the weakest in the whole network.

\section{CONCLUSION}

By taking ECNP as an example, this study explored the relevance of stakeholder participation in tourism management of peri-urban forests. We identified the key stakeholders, assessing their support and influence in tourism management of this park. Relationships are not being flexible tools for tourism management in this park; they are not facilitating communication of factors such as information, innovation or collaborative actions among stakeholder. Government bodies still have a relevant and dominant influence in decision making on tourism activities. The state has not transferred the control over decision making to user groups (stakeholders). Government agencies still are playing an important role as owners and managers of resources at local level.

Government agencies are still playing an important role as owners and managers of resources at a local level. Environmental protection agencies have particularly supported some tourism activities such as NRM, the CTS, and tourism management in this park. The quality of relationships between these agencies and CTAs are determined not only by knowledge exchange but also by economic support.

The transition from "government to governance" in this park is a difficult task; government bodies have marginalised other stakeholders in decision-making processes. We argue that governments rely on hierarchical authority; however, when they choose to govern in alternative ways, the state retains the main role in establishing and operating governance strategies. This approach emphasises the proliferation of complex horizontal forms of societal relations and governance networks in tourism management of peri-urban forests.

The inclusive management discourse has gained considerable momentum in the peri-urban forest and protected areas management research agenda. Sustainable management of these 
ecosystems is more effective when resource users participate in making and enforcing the tourism processes.

\section{REFERENCES}

[1] Erkus- Öztük, H. \& Eraydın, A., Environmental governance for sustainable tourism development: Collaborative networks and organization building in the antalya tourism region. Tourism Management, 31, pp. 113-124, 2010. http://dx.doi.org/10.1016/j.tourman.2009.01.002

[2] Madhumita, D. \& Chatterjee, B., Ecotourism: A panacea or a predicament? Tourism Management Perspectives, 14, pp. 3-16, 2015. http://dx.doi.org/10.1016/j.tmp.2015.01.002

[3] Conedera, M., Del Baggio, A., Seeland, K., Moretti, M. \& Home, R., Residents' preferences and use of urban and peri-urban green spaces. Urban Forestry \& Urban Greening, 14, pp. 139-147, 2015.

http://dx.doi.org/10.1016/j.ufug.2015.01.003

[4] van de Berg, A., Preference for nature in urbanized societies: Stress, restoration, and pursuit of sustainability. Journal of Social Issues, 63(1), pp. 79-96, 2007. http://dx.doi.org/10.1111/j.1540-4560.2007.00497.x

[5] Smink, K., Forests and recreation - new functions of afforestation as seen in Denmark (Chapter 7). New Perspectives on People and Forests, eds. E. Riiter \& D. Dauksta, Springer: New York, pp. 87-94, 2011.

[6] Jiaming, L., Run, W. \& Tian, C., Factor of spatial distribution of recreation areas in periurban Beijing. Journal of Geographical Sciences, 20(5), pp. 741-756, 2010. http://dx.doi.org/10.1007/s11442-010-0808-3

[7] Juffe-Bignoli, D., Burgess, N., Bingham, H., Belle, E., de Lima, M., Deguignet, M., Bertzky, B., Milam, A.N., Martinez-Lopez, J., Lewis, E., Eassom, A., Wicander, S., Geldmann, J., van Soesbergen, A., Arnell, A.P., O'Connor, B., Park, S., Shi, Y.N., Danks, F.S., MacSharry, B. \& Kingston, N., Protected Planet Report. United Nations Environment Programme, World Conservation Monitoring Centre. Cambridge: UNEP World Conservation Monitoring Centre, 2010.

[8] Tittensor, D., Walpole, M., Hill, S., Boyce, D., Britten, G. \& Burgess, N., A mid-term analysis of progress toward international biodiversity targets. Science, 346(6206), pp. 241-244, 2014. http://dx.doi.org/10.1126/science.1257484

[9] Törn, A., Siikamäki, P., Tolvanen, A., Kauppila, P. \& Rämet, J., Local people, nature conservation, and tourism in North-eastern Finland. Ecology and Society, 13(1), pp. 8-25, 2008.

[10] Jiaming, L., Run, W. \& Tian, C., Factor of spatial distribution of recreation areas in periurban Beijing. Journal of Geographical Sciences, 20(5), pp. 741-756, 2010. http://dx.doi.org/10.1007/s11442-010-0808-3

[11] Tyrväinen, L., Pauleit, S. \& de Vries, S., Benefits and uses of urban forests and trees (Chapter 4). Urban Forests and Trees, eds. C. Konijnendijk, K. Nilsson, T. Randrup \& J. Schipperijn, Springer: New York, pp. 81-114, 2005.

[12] Tyrväinen, L., Pauleit, S. \& de Vries, S., Benefits and uses of urban forests and trees (Chapter 4). Urban Forests and Trees, eds. C. Konijnendijk, K. Nilsson, T. Randrup \& J. Schipperijn, Springer: New York, pp. 81-114, 2005. 
[13] Leeuwis, C. \& Van de Ban, A., Communication for Rural Innovation: Rethinking Agricultural Extension, Wiley-Blackwell: Oxford, pp.27-55, 2004.

[14] Madhumita, D. \& Chatterjee, B., Ecotourism: A panacea or a predicament? Tourism Management Perspectives, 14, pp. 3-16, 2015. http://dx.doi.org/10.1016/j.tmp.2015.01.002

[15] Sekhar, U., Local people's attitude towards conservations and wildlife tourism around Sariska Tiger Reserve, India. Journal of Environmental Management, 69(4), pp. 339347, 2003. http://dx.doi.org/10.1016/j.jenvman.2003.09.002

[16] Natera, A., El liderazgo político en la sociedad democrática. Revista de Estudios Políticos, 118, pp. 385-421, 2001.

[17] Natera, A., Nuevas estructuras y redes de gobernanza. Revista Mexicana de Sociología, 118, pp. 755-791, 2005.

[18] Merinero, R., Desarrollo Local y Análisis de Redes Sociales: el valor de las relaciones como factor de desarrollo socioeconómico. REDES-Revista hispana para el análisis de redes, 18(11), pp. 1-28, 2015.

[19] Muñoz, A., Análisis relacional de sistemas turísticos. Un marco de trabajo alternativo en el proceso de planificación turística. Tourism and Management Studies, 8, pp. 55-64, 2012.

[20] Natera, A., Nuevas estructuras y redes de gobernanza. Revista Mexicana de Sociología, 118, pp. 755-791, 2005.

[21] Gobierno del Estado de Hidalgo., Cuarto Informe de Gobierno. Administración 20112016, Gobierno del Estado de Hidalgo: Pachuca de Soto, 2014.

[22] Wasserman, S. \& Faust, K., Social Network Analysis: Methods and Applications, University Press: England, pp. 177-192, 1994. http://dx.doi.org/10.1017/CBO9780511815478 